\title{
ETOS KERJA PADA NOVEL PERSEMBAHAN TERUNTUK BAPAK KARYA ADI ZAMZAM DAN PEMANFAATANNYA SEBAGAI BAHAN AJAR DI SMA
}

\author{
Cucu Fauziah', Imam Muhtarom², Sahlan Mujtaba ${ }^{3}$ \\ Universitas Singaperbangsa Karawang \\ Email : cucufauziah06@gmail.com ${ }^{1}$, arjotaruno@gmail.com ${ }^{2}$, \\ sahlanbahuy@gmail.com ${ }^{3}$
}

\begin{abstract}
Abstrak: Permasalahan yang timbul seperti kemiskinan, pengangguran, kesenjangan sosial dan lain-lain disebabkan oleh rendahnya etos kerja. Penelitian ini bertujuan untuk mendeskripsikan unsur-unsur intrinsik dan etos kerja pada novel Persembahan Teruntuk Bapak karya Adi Zamzam dan manfaatnya sebagai bahan ajar di SMA. Metode yang digunakan pada penelitian ini yaitu dengan menggunakan metode kualitatif deskriptif. Penelitian ini menggunakan subjek karya sastra yaitu novel karya Adi Zamzam yang berjudul Persembahan Teruntuk Bapak. Fokus yang diangkat pada penelitian ini yaitu berupa permasalahan yang berkaitan dengan etos kerja. Teknik pengumpulan data untuk penelitian ini dilakukan dengan teknik baca dan catat. Analisis data dilakukan dengan cara reduksi data, penyajian data, dan kesimpulan atau verifikasi data. Data pada penelitian ini berupa kalimat dan paragraf narasi. Hasil penelitian ini menunjukkan adanya etos kerja yang tinggi pada novel Persembahan Teruntuk Bapak yang tercermin melalui para tokoh di antaranya yaitu: pantang menyerah, sabar, tanggung jawab, kerja sama, kerja keras, terampil, jujur, disiplin dan bijaksana. Hasil penelitian ini memenuhi kriteria sebagai bahan ajar sastra kelas X di SMA, khususnya pada kompetensi dasar menulis teks novel melalui model Cooperative Integrated Reading and Composition (CIRC). Kesimpulan penelitian ini sebagai berikut. Novel Persembahan Teruntuk Bapak menyajikan para tokoh utama yang memiliki etos kerja tinggi sehingga para guru dimungkinkan menggunakannya sebagai sumber pembelajaran sastra di SMA.
\end{abstract}

Kata Kunci: etos kerja, karya sastra, novel Persembahan Teruntuk Bapak

\section{THE WORK ETHOS IN THE NOVEL TITLE PERSEMBAHAN TERUNTUK BAPAK BY ADI ZAMZAM AND ITS UTILIZATION AS TEACHING MATERIALS IN SENIOR HIGH SCHOOL}

\begin{abstract}
Problems that arise such as poverty, unemployment, social gaps and others are caused by work ethos. So this study aims to describe the intrinsic elements, the work ethic on the novel Persembahan Teruntuk Bapak works of Adi Zamzam and its benefits as a teaching material in high school. The method used in this research is by using the descriptive qualitative method. This study uses the subject of a literary work that is a literary work a novel by Adi Zamzam titled Persembahan Teruntuk Bapak. Focus raised in this study is in the form of the problems relating to work ethic. The technique of data collection for this research was conducted with the technique of read and record. Data analysis was done by data reduction, data presentation, and conclusion or verification data. The Data on this research in the form of sentences and paragraphs of the narrative. In accordance with the objectives of the study. The results of this study indicate that there is a high work ethic in the novel Persembahan Teruntuk Bapak who is responsible for the characters including: unyielding, patient, responsible, cooperative, work ethos, skilled, honest, disciplined and wise. The results of
\end{abstract}

BASASTRA Jurnal Bahasa, Sastra, dan Pengajarannya

Volume 9 Nomor 2, Oktober 2021, P-ISSN 2302-6405, E-ISSN 2714-9765 
this study meet the criteria for teaching literature for class $X$ in high school, especially in the basic competence of writing novel texts through the Cooperative Integrated Reading and Composition (CIRC) model. The conclusion of this research is as follows. The novel Persembahan Teruntuk Bapak presents the main characters who have a high work ethic so that it is possible for teachers to use them as a source of learning literature in high school.

Keywords: work ethic, works of literature, novel Persembahan Teruntuk Bapak

\section{PENDAHULUAN}

Perkembangan teknologi dan informasi dapat memberikan hasil positif dan negatif terhadap kehidupan dan berperilaku. Dampak positif tersebut tentunya dapat dengan mudah mendapatkan informasi, komunikasi, menambah pengetahuan dan lain sebagainya. Namun pada dampak negatifnya, yaitu dapat menyebabkan terjadinya pergeseran nilai-nilai moral, kecanduan game online, serta berpengaruh terhadap cara pandang dan pola pikir instan yang tidak sesuai dengan norma yang dapat menjadikan salah satu penyebab menurunnya kinerja yang dimiliki seseorang (Ilham \& Wijati, 2018). Hal tersebut dapat dilihat secara nyata pada berita-berita yang terdapat pada media online, televisi, dan lainnya. Hal ini seperti yang telah disampaikan oleh Nurgiyantoro (2015) bahwa selain mengandung segudang manfaat, disisi lain juga memiliki sifat ketergantungan dan dampak negatif seperti menurunnya minat belajar, kecanduan game online, lupa waktu, dan lain sebagainya (Kahfi, 2018).

Sebagai seorang siswa tugas utamanya adalah belajar, memahami dan mempelajari materi yang diajarkan, mengerjakan tugas-tugas yang diberikan guru, serta menaati peraturan-peraturan yang telah ditetapkan sekolah (Aziez \& Hasim, 2015). Akan tetapi, pada kenyataannya yang dapat dilihat saat ini, masih banyak siswa yang masih sulit dalam menaati aturan, sehingga terjadi tindakan membolos jam mata pelajaran, tawuran, tidak mengerjakan tugas-tugas yang diberikan guru, mencontek dan lain sebagianya.

Contohnya ketika siswa diberi tugas menulis, kebanyakan dari siswa mengerjakan tugas bukan hasil karyanya sendiri, melainkan hasil menyalin dari internet, atau menjiblak hasil temannya. Hal tersebut menunjukkan bahwa siswa tidak berusaha sendiri dalam menyelesaikan tugasnya. Padahal tugas-tugas yang diberikan guru kepada siswa sebagai bentuk evaluasi dan latihan agar siswa mengingat materi yang telah disampaikan dan melatih kreativitas siswa sehingga siswa dapat berinovasi dan kreatif (Prastowo, 2012). Adapun hal lain, masih banyak siswa yang terlambat masuk sekolah ataupun membolos dalam berlangsungnya kegiatan belajar mengajar (Utomo, Hasanah, \& Maryaeni, 2020).

Perilaku-perilaku tersebut menunjukan bahwa lemahnya rasa 
ingin belajar yang dimiliki siswa. Hal ini dapat berpengaruh terhadap hasil belajar peserta didik dan bisa menjadi sebuah kebiasaan yang kurang baik, serta dapat berpengaruh terhadap kualitas individu tersebut (Tantri, 2017; Pebrina, 2019). Perilaku mencontek menyebabkan siswa tidak ingin berusaha dan bekerja keras dalam mengerjakan dan menyelesaikan tugas yang dimilikinya (Nanang, 2018). Jika dibiarkan terus menerus cenderung menghasilkan dampak yang negatif dan tentu dapat mempengaruhi pembentukan sikap dan daya pikir yang tidak berkembang serta memengaruhi kualitas individu tersebut.

Mengingat

lingkungan

masyarakat dan sekolah sangat berbeda, kualitas dan etos kerja yang dimiliki siswa sangat berpengaruh dalam melawan kerasnya persaingan dalam kehidupan masyarakat (Suryadi, Azis, \& Utama, 2018; Elham, Hedjazi, Hosseini, \& Ebrahimi, 2011). Etos kerja sangat penting dimiliki siswa karena dapat menjadi bekal dalam menjalankan kehidupan setelah lulus dan bermanfaat bagi kelangsungan hidup peserta didik agar menjadi insan yang kuat, kreatif, inovatif dan menjadi sosok yang pantang menyerah terhadap sebuah tuntunan yang dihadapinya (Asifudin, 2004; Gunne \& Kajonius, 2015; Setyorini, Suwandi, \& Suyitno, 2016; Sinamo, 2018). Kurangnya etos kerja yang dimiliki seseorang dapat menjadi sebuah ancaman bagi kelangsungan hidup bangsa Indonesia karena dapat menjadi salah satu penyebab bertambahnya persoalanpersoalan seperti banyaknya pengangguran, kemiskinan, dan lain sebagainya (Sukma, Andayani, \& Mujiyanto, 2019; Fretwell, Lewis, \& Hannay, 2013).

Menurut Sri (2014), sekolah sebagai lembaga pendidikan yang paling depan dalam mengembangkan pendidikan karakter. Adapun dalam pendidikan karakter yang berkaitan dengan etos kerja ialah adanya pendidikan karakter kerja keras. Disisi lain sekolah sebagai tempat belajar akademis dan mengembangkan intelektual, sekolah juga berkewajiban memberikan pendidikan karakter terhadap peserta didik. Salah satu mata pelajaran yang dapat mendukung dalam membangun karakter siswa yaitu melalui pembelajaran sastra (Aminuddin, 2015).

Wibowo (2012) menyatakan bahwa sastra bukan hanya berfungsi sebagai agen pendidikan, membentuk keinsanan seseorang, tetapi juga memupuk kehalusan adab dan budi kepada individu serta masyarakat agar menjadi masyarakat yang berperadaban. Sastra melalui unsur imajinasinya, mampu membimbing siswa pada keluasan berpikir, bertindak, berkarya, dan sebagainya (Emzir \& Rohman, 2016; Wiyatmi, 2009). Pentingnya penelitian ini dilakukan adalah berkaitan dengan rendahnya etos kerja pada generasi muda, khususnya para siswa SMA 
sehingga dengan menghadirkan karya sastra yang sarat dengan muatan etos kerja dapat menjadi pendorong berkembangnya etos kerja yang baik pada siswa. Selain itu, hasil penelitian ini dapat menjadi referensi/kajian ilmiah novel dengan judul Persembahan Teruntuk Bapak karya Adi Zamzam dari aspek yang belum pernah diteliti oleh penelitian lain, yaitu nilai karakter etos kerja.

Kebaruan penelitian yang dilakukan ini adalah dengan adanya bahan ajar yang dapat tenaga pendidik terapkan, khususnya di lingkup SLTA/SMA. Mengingat beberapa penelitian terdahulu belum dibahas. Oleh akrena itu, penelitian ini bertujuan untuk mendeskripsikan unsur intrinsik, etos kerja dan mengetahui beberapa manfaat dari karya sastra. Hal tersebut dapat dikaitkan dengan manfaat karya sastra yang pengaruh cukup besar dalam menumbuhkan dan menanam kepribadian. Karya sastra dapat menjadikan individu yang beradab dan berbudi pekerti yang luhur. Karya sastra mampu menjadi alternatif dalam membangun kualitas perilaku suatu bangsa dengan menumbuhkan kepribadian anak bangsa (Sinamo, 2017).

\section{METODE}

Menurut Sugiyono (2017) metode deskriptif kualitatif adalah metode penelitian yang berdasarkan pada filsafat postpositivisme digunakan untuk meneliti pada kondisi objek yang ilmiah. Pendekatan penelitian ini menggunakan penelitian kualitatif. Penggunaan pendekatan penelitian kualitatif dianggap tepat untuk meneliti penelitian terhadap novel Persembahan Teruntuk Bapak karya Adi Zamzam dalam menganalisis etos kerja. Penelitian ini juga menggunakan metode yaitu metode deskriptif analisis. Metode ini dilakukan dengan cara mendeskripsikan fakta-fakta yang kemudian disusul dengan analisis.

Subjek dalam penelitian ini adalah novel Persembahan Teruntuk Bapak karya Adi Zamzam (Tarigan, 2015). Teknik pengumpulan data yang digunakan adalah teknik kepustakaan (Stanton, 2017). Teknik ini mengumpulkan data dengan menelaah buku, mencatat dan membuat laporan lainnya (Ratna, 2015). Bahwa dalam menganalisis data kualitatif dapat dilakukan secara interaktif dan berlangsung secara terus menerus sampai tuntas, sehingga datanya sudah jenuh (Sugiyono, 2017).

\section{Data Reduction}

Reduksi data berarti merangkum, memilih hal-hal yang pokok, memfokuskan pada hal-hal yang penting, dicari tema dan polanya. Pada tahap ini, peneliti merangkum dan mencatat data-data penting yang sesuai dan berkaitan dengan masalah yang akan dianalisis. Dalam hal ini berkaitan dengan sruktur pembangun novel yaitu unsur intriksik dan etos kerja yang 
terdapat pada novel Persembahan Teruntuk Bapak karya Adi Zamzam. Informasi-informasi yang mengacu pada permasalahan itulah yang menjadi data pada penelitian.

\section{Data Display}

Setelah tahap reduksi data, maka Langkah selanjutnya adalah mendisplay data. Pada penelitian kualitatif, penyajian data bisa dilakukan dalam bentuk uraian singkat, bagan, hubungan antar kategori, flowchart dan sejenisnya. Pada tahap ini, peneliti akan menguraikan dan Menyusun sesuai urutan terhadap hasil dari reduksi data dalam bentuk uraian singkat, data yang telah ditemukan dalam novel Persembahan Teruntuk Bapak karya Adi Zamzam akan di deskripsikannya dengan menggunakan teks naratif.

\section{Conclusion Data/Verification}

Langkah ketiga atau Langkah terakhir dari analisis data kualitatif menurut Niles dan Huberman adalah penarikan kesimpulan dan verifikasi. Pada tahap ini, peneliti menyimpulkan hasil data yang telah diperoleh peneliti dalam novel Persembahan Teruntuk Bapak karya Adi Zamzam.

Berikut merupakan bagan tahapan yang dilakukan pada Gambar 1 .

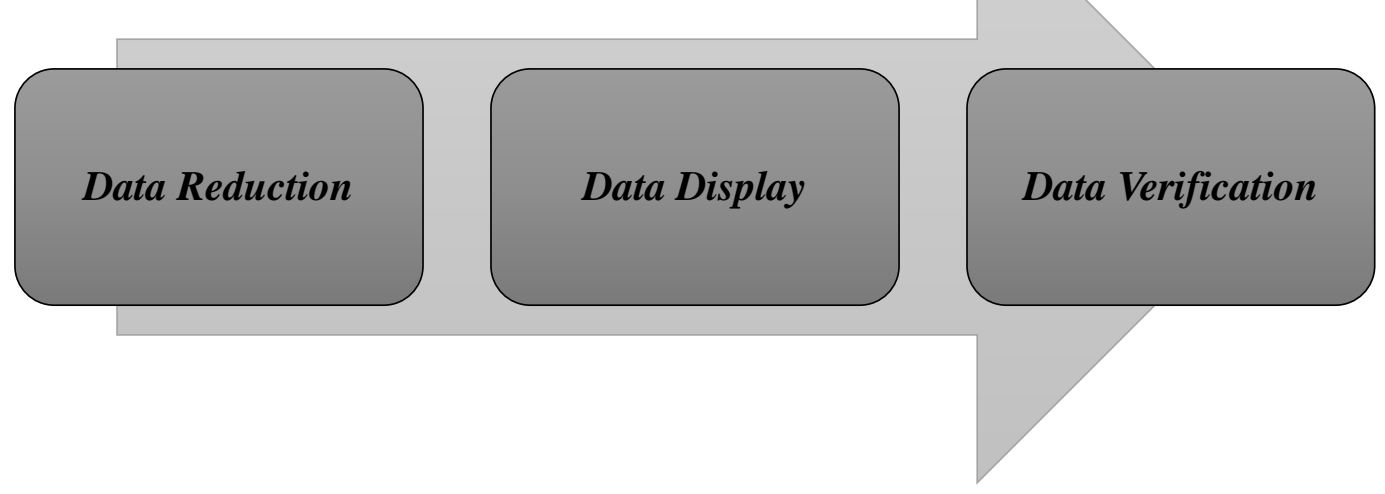

Gambar 1. Bagan Tahapan Analisis Data

\section{HASIL DAN PEMBAHASAN}

Dari analisis muatan etos kerja dalam novel Persembahan Teruntuk Bapak karya Adi Zamzam (AZ) meliputi karakter pantang menyerah, sabar, tanggung jawab, kerja sama, kerja keras, terampil, jujur, disiplin dan bijaksana. Secara rinci masing-masing karakter tersebut disajikan pada uraian dan contoh-contoh bagian teks yang relevan sebagai berikut ini. 


\section{Pantang menyerah}

\section{Pantang}

menyerah

menunjukkan sikap untuk tidak mudah putus asa dalam menghadapi suatu keadaan. Sikap pantang menyerah pada novel ini berhubungan dengan perjalanan kehidupan yang dialami oleh para tokoh. Sikap pantang menyerah ditunjukkan oleh Bambang yang selalu optimis dan percaya diri. Seperti pada kutipan berikut:

"Pokoknya ini demi karirku sendiri. Kau mungkin tak tahu, Tuhan itu punya banyak cara untuk membawa seseorang kepada impian yang diinginkannya. Bisa jadi, segala kesusahan yang dilaluinya di depan, adalah cara-Nya untuk mematangkan proses menjadi," sambil mematut wajah di depan cermin tempat wudhu pria di mushala." (Data -01)

Dari kutipan di atas tergambar bahwa Bambang merupakan sosok yang pantang menyerah dalam mengejar mimpinya. Ia percaya diri dan yakin bahwa kesusahan yang sekarang dilaluinya adalah sebuah proses yang harus dilalui untuk mencapai kesuksesan. Seperti pada penokohan, Bambang sebagai tokoh yang selalu optimis dan percaya diri. Kepercayaan diri Bambang membuatnya selalu bersemangat seperti yang dapat dilihat pada kutipan berikut:
“Ayo, Ya, baca dulu," senggolan bahu Bambang membuyarkan lamunan Arya." (Data -04)

"Arya menoleh sengit," Males, Mbang," Arya melemparkan begitu saja buah tangan Bambang itu ke meja." (Data 05)

"Benar-benar tak berperikemanusiaan, mengambil kembali kertas yang tadi dibuang Arya. "Padahal aku menuliskannya dengan susah payah," rautnya menyedihkan." (Data -07)

"Aku menyalinnya dari $\mathrm{Ki}$ Hudoyo Sikocarito yang manggung setiap malam jum'at di Radio Kalingga." (Data -08)

"Arya menggeleng-geleng
kepala. Dahinya berkerut.
Separah inikah sahabatnya
terobsesi dengan wayang? Buat
apa? " Menyalinnya?
Maksudmu?" meski dibaca
juga." (Data-10)

Kutipan di atas menggambarkan tokoh Arya yang sedang mengacuhkan Bambang saat ia ingin Arya melihat hasil kerja kerasnya dalam menghasilkan sebuah teks naskah. Namun dengan semangat dan sabar, Bambang tetap membujuk Arya agar ia melihat hasil pekerjaan 
Bambang. Tokoh Bambang selalu memiliki semangat dan pantang menyerah terutama untuk memenuhi keinginannya. Seperti pada saat Bambang ingin belajar mendalang untuk pertama kalinya, meskipun ia harus mendapatkan olokan karena memiliki keturunan Arab, namun semangatnya tidak pernah padam. Seperti pada kutipan berikut:

"Wooii... teman-teman, lihat, turis Arab kita mau belajar mendalang!" Noval mengacungkan wayang-wayang itu di depan kelas." (Data-15)

"Heee... bumi gonjang-gonjing rambut keriting, hahaha!.” (Data -18)

Kutipan di atas merupakan lontaran ledekan dari Noval terhadap Bambang, Noval dengan Bambang memang tidak pernah akur, seperti kucing dan anjir, selalu bertengkar dan Bambang selalu menjadi bahan ledekannya. Namun semangat Bambang tak pernah padam. Seperti yang terdapat pada kutipan berikut:

"Masih bersemangat belajar mendalang di sini?" ujar Arya setelah Bambang kembali duduk tenang." (Data -23)

"Kita pilih tempat aman. Tempat parkir sepeda saja," terdengar masih menyimpan emosi." (Data $-25)$
"Arya geleng-geleng kepala."

(Data -26)

Dari kutipan di atas sebagai bukti betapa gigih dan semangatnya Bambang dalam mengejar dan mendapatkan apa yang diinginkannya. Bambang memang memiliki sifat yang mudah terpancing emosi. Meskipun telah direndahkan dan di ejek. Namun, hal itu tidak sedikit pun menjadi hambatan untuk menyerah dan membuang cita-citanya. Justru membuatnya semakin bersemangat dalam mencapai keinginannya.

\section{Sabar}

Sabar merupakan ciri dari pekerja keras. Sikap sabar menjadikan seseorang tahan terhadap suatu ujian ataupun cobaan yang dihadapi dengan tidak mudah marah dan tidak mudah putus asa. Dalam novel ini, penulis menggambarkan tokoh Arya yang memiliki sikap sabar. Penggambaran sikap sabar tersebut dapat dilihat pada kutipan berikut:

"Baa...! ternyata Dewa Ruci jualan koran ya, hahaha...!" tak dinyana sebuah suara muncul dari balik kaca sebuah mobil Kijang yang dihampiri Arya. Dua wajah yang amat ia kenal muncul dari balik kaca warna gelap. Ternyata Noval dan Joko. Arya buru-buru membalikkan tubuh dan menjauh dari mobil itu." (Data -29) 
"Woi, Dewa Ruci, kami mau beli korannya!” mereka masih saja memanggil dengan tawa. Namun Arya tak menoleh sedikitpun. Ia tahu mereka hanya niat mengerjai." (Data -30)

Kutipan di atas menggambarkan bahwa Arya bersikap sabar. Saat ada temannya yang melihat Arya berjualan koran. Ia tahu bahwa temannya hanya merendahkan dirinya dan mengejeknya. Dengan mengoloknya sebagai penjual koran. Ketika mendengar kata-kata Noval, Arya lebih memilih untuk pergi dan mengabaikannya dan berusaha menahan dirinya untuk tidak emosi dan marah atas ejekan yang telah dilontarkan oleh temannya itu. Hal ini menunjukkan bahwa Arya sedang berupaya untuk bersikap sabar.

\section{Tanggung jawab}

Tanggung jawab merupakan kemampuan untuk menanggung dan melaksanakan tugas yang telah diberikan kepada terhadap diri sendiri, masyarakat, lingkungan, negara dan tuhan yang maha esa. Pada kutipan di bawah ini merupakan bentuk tanggung jawab yang dilakukan oleh tokoh, sebagai berikut:

"Ini, Mak," Arya menyerahkan selembar sepuluh ribuan kepada emaknya." (Data -36)

"Simpan buat biaya sekolahmu saja," Mak Rosdah menolaknya.
Padahal biasanya beliau menerima setiap pemberian Arya, meskipun hanya seribu rupiah. "(Data -37)

"Arya sudah menyimpan sebagiannya. Tadi pagi Arya mengambil koran tambahan. Rotinya Mbak Ima yang Arya titipkan di beberapa toko juga banyak yang sudah habis. Jadi Emak tak perlu khawatir denganku." (Data-38)

Pada kutipan di atas, menggambarkan bentuk tanggung jawab tokoh Arya terhadap keluarganya. Sebagai anak, pasti ingin membantu orang tuanya jika sedang kesulitan, apalagi dia tahu bahwa keuangan keluarganya tidak stabil. Hal tersebut membuat Arya bekerja untuk menambah-nambah pemasukan dan meringankan orang tuanya. Tidak hanya Arya, bentuk tanggung jawab juga digambarkan oleh Ratri, sebagai kakak tertuanya. Seperti pada kutipan berikut:

"Tri... waktunya latihan!" Terdengar panggilan dari bawah." (Data -43)

"Sebentar!" balas Ratri. "Ini ambillah." Gadis itu buru-buru menyelipkan dua lembar ratusan ribu ke saku baju Arya. Ah, lagilagi. Andai saja bapaknya tahu 
bahwa Mbakyunya ini juga ikut memperjuangkan keluarganya. entah kenapa mereka terus saja bertengkar." (Data-44)

Kutipan di atas, menggambarkan bentuk tanggung jawab Ratri yang diberikan kepada keluarganya. Meskipun ayahnya menilai pekerjaannya buruk dan selalu berbeda sudut pandang dengannya, tapi Ratri tidak pernah melupakan keluarganya. Ia selalu berusaha membantu keluarganya semampunya.

\section{Kerja sama}

Kerja sama merupakan suatu usaha yang dikerjakan secara bersamasama untuk mencapai tujuan tertentu yang telah direncanakan. Pada kutipan di bawah ini menggambarkan sikap kerja sama yang dilakukan oleh para tokoh dalam cerita:

"Begini saja, nanti, biar aku saja yang coba ndang. Sedang tugasmu, menjajakan wayangnya," tak peduli dengan perlakuan Arya. "wayangnya bisa dijiplak, tapi keunikan kita, coba saja kalau bisa!" (Data -49)

\begin{tabular}{|c|}
\hline 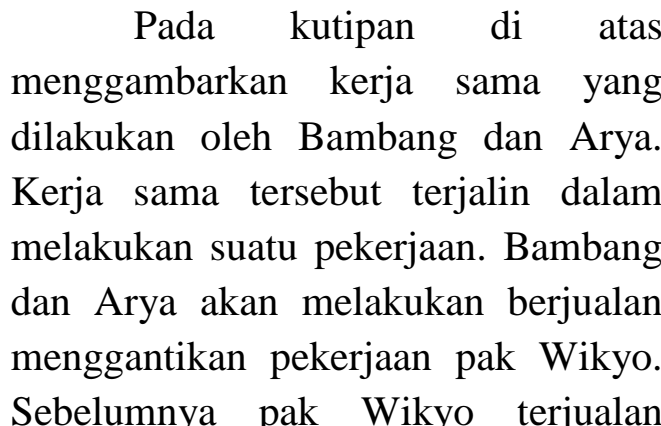 \\
\hline
\end{tabular}

mainan untuk menafkahi keluarganya. Namun karena sakit, Arya selaku anaknya harus menggantikan. Bambang sebagai sahabatnya Arya ingin membantu sehingga terjalin suatu hubungan kerja sama.

Kepindahan Bambang ke Jogja, membuat kerja sama mereka terputus. Namun, setelah kembalinya Bambang, kerja sama itu terjalin kembali dengan tujuan yang berbeda. Bambang mengenalkan Arya kepada seseorang untuk belajar mendalang bersamanya untuk mencapai mimpi mereka berdua. Seperti pada kutipan berikut:

"Oh, saya idem saja dengan Profesor. Kami baru saja makan tadi, di rumah," sahut pak Roto, yang kemudian memperkenalkan diri. Beliau adalah seorang abdi dalem jajar. Selama mendalami seluk beluk pewayangan di sekolah dalang Habirandha, Propesor Philip menginap di rumah Pak Roto." (Data -52)

"Jadi kamu yang bernama Arya Sena?" tanya Profesor Philip, setelah Pak Roto menutup ceritanya." (Data -53)
"Iya Prof." (Data -54)
"Aku bisa membantumu untuk bisa ikut tampil di Festival Dresdner nanti. Jadi, kau tak perlu sungkan. Aku suka dengan 
anak muda yang sudah pandai mendalang (Data -56)

Pada kutipan di atas, perkenalan yang terjalin antara profesor Philip, Bambang dan Arya memiliki tujuan untuk meminta bantuan dan menjalin kerja sama dalam melatih dan membimbing mereka agar dapat mengikuti sebuah festival mendalang.

\section{Kerja keras}

Kerja keras Sikap yang menunjukkan kesungguhan dalam melakukan dan mengatasi berbagai hambatan baik dalam belajar serta menyelesaikan tugas dengan baik. Dalam novel ini sikap kerja keras digambarkan oleh tokoh yang terdapat pada cerita. Seperti pada kutipan berikut:

"...Arya mencoba membetulkan beberapa mainan yang masih bisa diselamatkan. Ia tahu, kelahiran setiap mainan itu tidaklah gampang. Bapaknya sering bergadang untuk menyelesaikan beberapa mainan yang habis di beli orang." (Data $-58)$

Pada kutipan di atas menggambarkan bentuk kerja keras yang dilakukan pak Wikyo sebagai kepala keluarga dalam mencari nafkah. Kerja kerasnya sebagai penjual mainan sering kali membuatnya bergadang untuk menyiapkan bahan yang akan dijual. Seperti yang telah dijelaskan pada penokohan, pak Wikyo merupakan mantan seorang dalang yang populer. Namun karena insiden yang menimpanya membuatnya harus kehilangan semua itu. Kini ia harus berusaha keras untuk mencukupi keluarganya dengan berjualan mainan keliling.

"Ia tak bisa membuang bayangan itu. Jadi iya harus bisa menerimanya secara wajar. Hampir setiap hari ia melihat bapaknya yang berjemur demi menjajakan mainan wayangnya. Wayang-wayang itu dimainkan dengan suara lantang untuk menarik perhatian, membuat ingatan Arya tentang pertunjukan-pertunjukan bapaknya perlahan muncul setelah lama menghilang. Bisa dibayangkan jika hari beranjak semakin siang. Bisa dibayangkan bagaimana beliau harus menghadapi tatapan aneh sesama penjual. Bisa dibayangkan rasa gengsi beliau lawan dari seorang dalang profesional namun kemudian berakhir menjadi dalangdalangan." (Data -62)

Sebagai seorang dalang yang telah kehilangan ketenaran, tentu bisa membuat Pak Wikyo hancur, dan tentu ada rasa malu yang tertanam dalam dirinya. Namun, demi keluarganya dan tanggungjawabnya sebagai kepala keluarga, ia rela bekerja keras panas- 
panasan hingga mungkin menghilangkan rasa gengsi yang dimilikinya. Selain itu, sikap kerja keras juga digambarkan oleh Arya dan Bambang.

\section{Terampil}

Terampil adalah sikap yang menunjukkan kepandaian seseorang dalam mengerjakan atau melakukan suatu hal. Sikap terampil pada novel ini digambarkan oleh para tokoh. Seperti yang terdapat pada kutipan berikut:

"Setelah semua bilah-bilah bambu selesai dikerjakan, keduanya pun kembali masuk ruang tamu. Bambang langsung takjub dengan pemandangan yang kemudian didapatinya. Lelaki itu telah menyelesaikan beberapa sketsa wayang pada kertas karton. Tampak begitu nyata dan detail gambarnya." (Data -64)

Pada kutipan tersebut tergambar keterampilan pak Wikyo dalam menyelesaikan pekerjaannya, membuat wayang mainan untuk berjualan. Hal tersebut membuat Bambang takjub dengan kepandaian pak Wikyo dalam menghasilkan gambar yang terlihat begitu nyata dimatanya.

\section{Disiplin}

Disiplin merupakan sikap patuh kepada peraturan yang telah ditetapkan. Disiplin tidak hanya tentang peraturan namun tentang ketepatan waktu juga harus diperhatikan. Disiplin dalam novel ini terdapat pada kutipan berikut:

"Pagi yang berdebu di bulan September. Arya mengayuh sepedanya keras-keras. Mengejar waktu. Beberapa koran telah ia setorkan ke para pelanggan tetap." (Data -68)

Pada kutipan di atas, menggambarkan bahwa Arya merupakan pekerja yang disiplin. Seperti yang telah digambarkan pada penokohan, bahwa selain sekolah, Arya juga memiliki pekerjaan sebagai loper koran. Hal tersebut menjadikan Arya harus disiplin dengan waktu yang ia miliki agar tidak perlu mengorbankan salah satu dari sekolah dan pekerjaannya. Sudah menjadi etikanya dia menyampaikan koran kepada pelanggan tetapnya dengan tepat waktu dan pelanggan tidak kecewa karena harus menunggu. Selain itu, ia juga tidak akan mendapat teguran dari atasannya. Namun, ia juga harus tetap mematuhi peraturan yang telah ditetapkan oleh sekolah untuk datang tepat waktu. Hal tersebut tentu membuat Arya harus mengatur waktunya dengan baik.

Kedisiplinan juga terjadi di tempat berjualan Ayahnya Arya, pak Wikyo. Terdapat peraturan antara pedagang yang harus dilaksanakan. Kedisiplinan yang terjadi pada tempat pak Wikyo berjualan seperti pada kutipan berikut: 
"Apa Emak melihat dua kotak yang..." (Data -69)

"Perempuan itu langsung menunjukan ke benda yang dimaksud Arya." Peraturannya di sini, setiap pedangang harus ada jarak dengan yang lain.

Karena kau orang baru, jadi kamu kebagian tempat ujung." (Data -71) sebuah peraturan yang harus dilaksanakan oleh pak Wikyo di sekolah tempatnya berjualan. Peraturan yang ditetapkan tersebut dapat berguna untuk menertibkan para pedagang agar tidak saling berebut tempat antara yang lama dengan yang baru dan juga memiliki tempatnya masing-masing sesuai yang telah ditentukan. Dapat disimpulkan alur hasil pada penulisan yang telah dilakukan pada tahapan analisis etos kerja, pada Gambar 2.

Pada kutipan di atas, menggambarkan bahwa terdapat

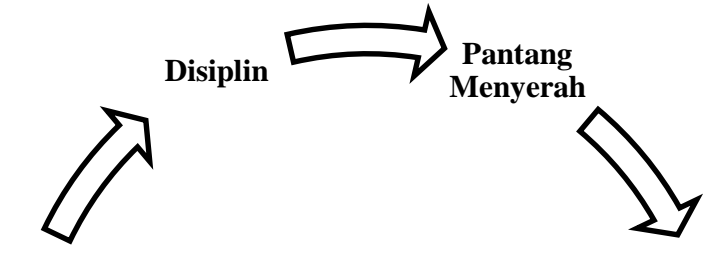

Terampil

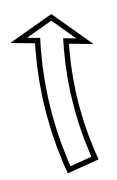

Kerja Keras
Sabar

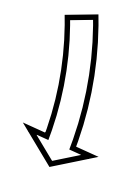

Tanggung
Jawab

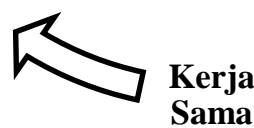

Gambar 2. Tahap Analisis Etos Kerja

Pemanfaatan Novel PTB dalam Pembelajaran di SMA

Berdasarkan hasil wawancara dengan guru dan dosen diperoleh informasi bahwa kajian terhadap etos kerja dalam novel Persembahan Teruntuk Bapak (PTB) dapat digunakan sebagai materi ajar kompetensi dasar (KD) 3.9, yaitu menganalisis isi dan kebahasaan novel untuk indikator (a) dapat mengidentifikasi unsur intrinsik, (b) ekstrinsik, dan (c) kebahasaan novel. Selain itu, hasil penelitian terhadap novel tersebut juga dapat 
dimanfaatkan sebagai materi ajar KD 4.9 yaitu merancang novel atau novelet dengan memerhatikan isi dan kebahasaan baik secara lisan maupun tulis dengan indikator (a) dapat menyusun novel berdasarkan rancangan dan mempresentasikan, merevisi dan (b) mengomentari unsur intrinsik dan ekstrinsik serta kebahasaan novel, hasil penyusunan novel.

Pemanfaatan novel Persem-

bahan Teruntuk Bapak dalam pembelajaran menganalisis isi dan kebahasaannya menurut informan dilakukan dengan metode jigsaw. Untuk itu kelas dibagi menjadi 3 kelompok asal, yang kemudian setiap kelompok mengirimkan anggotanya dalam 3 kelompok ahli. Kelompok ahli pertama membahas nilai etos kerja para tokohnya, kelompok ahli 2 membahas unsur instrinsik novel, sedangkan kelompok ahli 3 membahas unsur kebahasaannya. Setelah kelompok ahli berdiskusi, masing-masing wakil kembali ke kelompok asal untuk melakukan sharing dengan kelompok tersebut. Selanjutnya mereka mengerjakan lembar kerja siswa secara individual. Soal yang diberikan mayoritas meminta siswa memberikan penilaian tokoh yang memiliki etos kerja positif dan negatif, juga tokoh yang patut diteladani dan tidak layak untuk diikuti perilakunya. Jika ada anggota yang belum mencapai batas kelulusan, kelompoknya dengan dipandu guru akan membantu untuk memberikan pemahamannya. Pada kegiatan refleksi guru menunjukkan alur etos kerja seperti pada Gambar 2 yang termuat pada novel yang telah dibaca siswa.

Untuk melaksanakan tujuan pembelajaran merancang novel atau dengan memperhatikan isi dan kebahasaan secara tulis, novel yang menjadi fokus penelitian ini dapat menjadi stimulus pada penerapan model CIRC (Cooperative Integrated Reading and Composition). Menurut infotman, langkah pembelajaran model tersebut sebagai berikut ini. Mula-mula siswa diminta membaca novel PTB dan menemukan etos kerja di dalamnya. Siswa bersama kelompoknya mengidentifikasi etos kerja yang akan diadopsi dalam rancangan novelnya. Siswa membuat rancangan novel, kemudian mengembangkannya menjadi draf. Selanjutnya siswa melakukan revisi untuk menghasilkan novel final.

Berdasarkan hasil kajian dalam penelitian ini diperoleh unsur-unsur positif dalam novel PTB, yaitu etos kerja yang dapat menjadi inspirasi pembacanya, termasuk para siswa SMA. Etos kerja yang dimaksud meliputi pantang menyerah, sabar, tanggung jawab, kerja sama, kerja keras, terampil, jujur, disiplin, dan bijaksana. Nilai yang positif tersebut layak menjadi teladan bagi siswa SMA.

Temuan penelitian ini sejalan dengan beberapa hasil penelitian sebelumnya yang menemukan adanya

BASASTRA Jurnal Bahasa, Sastra, dan Pengajarannya 
nilai karakter positif dalam novel-novel Indonesia. Beberapa penelitian tersebut menemukan nilai karakter cinta tanah air, religius, nilai sosial, nilai moral (Tantri, 2017; Suryadi, Azis, \& Utama, 2018; Sukma, Andayani, \& Mujiyanto, 2019; Setyorini, Suwandi, \& Suyitno, 2016; Pebrina, 2019; Nanang, 2018; Ilham \& Wijati, 2018). Akan tetapi, penelitian ini secara khusus menemukan adanya nilai karakter etos kerja.

Etos kerja merupakan nilai karakter yang harus dikembangkan mengingat sebagian generasi muda belum memiliki karakter tersebut dan pembelajaran di sekolah menjadi jembatan yang paling memungkinkan untuk hal itu. Sebagaimana dinyatakan Ilham dan Wijati (2018) bahwa pengembangan nilai karakter paling efektif jika dilakukan di sekolah dan mata pelajaran Bahasa Indonesia mendapat porsi tertinggi karena pembelajarannya dilakukan berbasis teks, termasuk teks sastra. Melalui teks sastra, siswa dapat meresepsi niali-nilai keteladanan para tokohnya, termasuk keteladanan etos kerja. Dari kegiatan meresepsi yang bersifat kognitif akan berefek pada aspek efaktif, bahkan psikomotor (Sukma, et al., 2019)

\section{SIMPULAN}

Sesuai dengan tujuan penelitian, hasil penelitian ini membahas mengenai: etos kerja yang tercermin melalui para tokoh diantaranya yaitu: pantang menyerah, sabar, tanggung jawab, kerja sama, kerja keras, terampil, jujur, disiplin, dan bijaksana. Pantang menyerah menunjukkan sikap untuk tidak mudah putus asa dalam menghadapi suatu keadaan. Sikap pantang menyerah pada novel ini berhubungan dengan perjalanan kehidupan yang dialami oleh para tokoh. Sabar merupakan ciri dari pekerja keras. Sikap sabar menjadikan seseorang tahan terhadap suatu ujian ataupun cobaan yang dihadapi dengan tidak mudah marah dan tidak mudah putus asa. Tanggung jawab merupakan kemampuan untuk menanggung dan melaksanakan tugas yang telah diberikan kepada terhadap diri sendiri, masyarakat, lingkungan, negara dan tuhan yang maha esa. Kerja sama merupakan suatu usaha yang dikerjakan secara bersama-sama untuk mencapai tujuan tertentu yang telah direncanakan. Kerja keras Sikap yang menunjukkan kesungguhan dalam melakukan dan mengatasi berbagai hambatan baik dalam belajar serta menyelesaikan tugas dengan baik. Terampil adalah sikap yang menunjukkan kepandaian seseorang dalam ngerjakan atau melakukan suatu hal. Disiplin merupakan sikap patuh kepada peraturan yang telah ditetapkan. Disiplin tidak hanya tentang peraturan namun tentang ketepatan waktu juga harus diperhatikan.

Kontribusi penelitian ini adalah sekolah sebagai lembaga pendidikan yang paling depan dalam mengembangkan pendidikan karakter. Adapun 
dalam pendidikan karakter yang berkaitan dengan etos kerja adalah adanya pendidikan karakter kerja keras. Di sisi lain sekolah sebagai tempat belajar akademis dan mengembangkan intelektual, sekolah juga berkewajiban memberikan pendidikan karakter terhadap peserta didik. Salah satu mata pelajaran yang dapat mendukung dalam membangun karakter siswa yaitu melalui pembelajaran sastra. Dengan demikian, hasil penelitian ini mendukung KD dan IPK yang telah ada. Sehingga dengan harapan dapat dijadikan sumber referensi ilmiah mengenai etos kerja melalui karya sastra yaitu novel.

\section{REFERENSI}

Aminuddin. (2015). Pengantar Apresiasi Karya Sastra (1st ed.). Bandung: Sinar Baru Algesindo.

Asifudin, A. J. (2004). Etos Kerja Islami (1st ed.). Surakarta: Muhammadiyah University Press.

Aziez, F., \& Hasim, A. (2015). Menganalisis Fiksi : Sebuah Pengantar (1st ed.). Bogor: Graha Indonesia.

Elham, S., Hedjazi, Y., Hosseini, S. M., \& Ebrahimi, M. S. (2011). The Effect of Personality Types on the Learning Styles of Agricultural Students (A Case Study in Iran). The Online Journal of New Horizons in Education, 4(2), 126135.
Emzir, \& Rohman. (2016). Teori dan Pengajaran Sastra (1st ed.). Jakarta: PT. Raja Grafindo Persada.

Fretwell, C. E., Lewis, C. C., \& Hannay, M. (2013). Myers-Briggs Type Indicator, A/B Personality Types, and Locus of Control: Where Do They Intersect? American Journal of Management, 8(3), 57-66.

Gunne, G., \& Kajonius, P. (2015). Personality Traits and Values: A Replication with a Swedish Sample. International Journal of Personality Psychology, 1(1), 814.

Ilham, M., \& Wijati, I. A. (2018). Nilai Pendidikan Karakter Demokratis dan Toleransi dalam Novel Karya Habiburrahman El Shirazy dan Relevansinya dengan Pembelajaran Sastra. Kode: Jurnal Bahasa, 7(4), 1-10.

Kahfi, M. R. (2018). Nilai Toleransi dalam Novel "Ayat-Ayat Conta 2" Karya Habiburrahman El-Shirazy. Locana: Jurnal Tugas Akhir Mahasiswa PS PBSI FKIP ULM, I(1), 18-26.

Nanang, H. P. (2018). Nilai Karakter Kerja Keras dan Nilai Karakter pada Novel Peluang Karya Tere Liye dan Kemungkinannya sebagai Alternatif Bahan Ajar dalam Pembelajaran Sastra di SMA. Semarang: Universitas Negeri Semarang. 
Nugiyantoro, B. (2015). Teori Pengkajian Sastra (1st ed.). Yogyakarta: Gadjah Mada University Press.

Pebrina, S. (2019). Karakter Kerja Keras Tokoh Utama dalam Novel Bodadaro Bermata Bening Karya Habiburrahman El Shirazy Kajian Psikologi Sastra. Aceh: Universitas Sumatera Utara.

Prastowo, A. (2012). Panduan Kreatif Membuat Bahan Ajar Inovatif : Menciptakan Metode Pembelajaran yang Menarik dan Menyenangkan (1st ed.). Yogyakarta: Diva Press.

Ratna, N. K. (2015). Teori, Metode, dan Teknik Penelitian Sastra (1st ed.). Yogyakarta: Pustaka Belajar.

Setyorini, R., Suwandi, S., \& Suyitno. (2016). Kepribadian Tokoh Utama dan Nilai Pendidikan Kerja Keras pada Novel Entrok Karya Okky Madasari dan Relevansinya dengan Pembelajaran Sastra di Peguruan Tinggi (Kajian Psikologi Sastra). Jurnal S2 Pendidikan Bahasa Indonesia, I(1), 35-47.

Sinamo, J. (2018). Delapan Etos Kerja Profesional (1st ed.). Jakarta: Institut Mahardika.

Sri, N. (2014). Pendidikan Karakter : Pengintegrasian 18 Nilai Pembentuk Karakter dalam Mata Pelajaran (1st ed.). Yogyakarta: Familia.

Stanton, R. (2017). Teori Fiksi (1st ed.). Yogyakarta: Pustaka Belajar.
Sugiyono. (2017). Metode Penelitian Kuantitatif, Kualitatif dan $R \& D$ (1st ed.). Bandung: CV. Alfabeta.

Sukma, A., Andayani, \& Mujiyanto, Y. (2019). Kajian Sosiologi Sastra dan Nilai Toleransi pada Novel Kambing dan Hujang Karya Mahfud Ikhwan serta Relevansinya dengan Materi Ajar Apresiasi Sastra di SMA Kelas XII. Basastra: Jurnal Penelitian Bahasa, Sastra Indonesia dan Pengajarannya, 6(2), 40-52.

Suryadi, J., Azis, M. M., \& Utama, S. A. (2018). Refleksi Toleransi dalam Novel "Hujan" Karya Tere Liye. Malang: Senasbasa (Seminar Nasional Bahasa dan Sastra).

Tantri, A. A. (2017). Nilai-Nilai Pendidikan Karakter dalam Novel Tantri (Perempuan yang Bercerita) Karya Cok Sawitri sebagai Alternatif Pembelajaran Sastra di Sekolah Dasar. Semarang: The 1st Education and Language International Conference Proceedings Center for International Language Development of Unissula.

Tarigan, H. G. (2015). Prinsip-Prinsip Dasar Sastra (1st ed.). Bandung: Angkasa.

Utomo, R. O., Hasanah, M., \& Maryaeni. (2020). Telaah Nilai Toleransi Sosial dalam Novel Karya Ahmad Tohari. Jurnal Pendidikan: Teori, Penelitian, dan Pengembangan, 5(6), 792-802. 
Wibowo, A. (2012). Pendidikan Karakter Berbasis Sastra : Internalisasi Nilai-Nilai Karakter Melalui Pengajaran Sastra (1st ed.). Yogyakarta: Pustaka Belajar.

Wiyatmi. (2009). Pengantar Kajian Sastra (1st ed.). Yogyakarta: Pustaka Book.

Zamzam, A. (2017). Persembahan Teruntuk Bapak (1st ed.). Yogyakarta: Diva Press. 